\title{
KESULITAN MENYIMAK DALAM PEMBELAJARAN BAHASA INDONESIA \\ (Penelitian Studi Kasus Pada Siswa Kelas 3 Sekolah Dasar Inklusi X Bandung)
}

\author{
Rai Bagus Triadi, S.S., M.Pd. ${ }^{1} \&$ Tri Pujiati, S.S., M.M., M.Hum. ${ }^{2}$ \\ Universitas Pamulang \\ Email: mollykejora12@gmail.com
}

\begin{abstract}
Abstrak
Kesulitan menyimak menjadi hambatan masuknya informasi kepada siswa. Hambatan tersebut dapat berupa salah persepsi atau tidak utuhnya informasi yang sampai kepada siswa. Tujuan dari penelitian ini adalah untuk menemukan sebuah kasus pada pembelajaran menyimak yang tampak sebagai sebuah penyimpangan, kemudian penyimpangan tersebut dianalisis berdasarkan tahapan untuk melihat faktor-faktor yang melatarbelakangi penyimpangan tersebut, sedangkan tahap akhir penelitian kasus ini adalah memberikan tanggapan berupa perlakuan dalam konteks tertentu atau dalam penelitian studi kasus biasa disebut tahap evaluasi. Penelitian ini menggunakan metode penelitian naturalistik deskriptif kualitatif untuk memperoleh data secara sistematis, faktual, dan akurat. Data dalam penelitian ini berupa data lisan dan tulis. Data lisan diperoleh dengan menggunakan teknik pengumpulan data berupa wawancara dan observasi pada siswa, sedangkan data berupa tulisan diperoleh dengan menggunakan instrumen berupa tes. Hasil penelitian menunjukkan bahwa (1) kesulitan menyimak yang dialami siswi (X) disebabkan oleh terganggunya indera pendengaran; (2) gangguan indera pendengar terjadi karena siswi (X) mengalami kecelakaan di kolam renang umum; (3) motivasi dari guru sangat berperan untuk kasus yang dialami oleh siswi (X); (4) siswi (X) memerlukan layanan khusus dalam proses pembelajaran keterampilan menyimak.
\end{abstract}

Kata Kunci: menyimak, studi kasus, dan gangguan indera pendengar

\section{Abstract}

The difficulty of listening become entry barriers to student information. Barriers could be any perception or wholeness of the information is up to the student. The purpose of this research is to find a case of learning to listen appears to be an aberration, then the deviation is analyzed based on the stage to look at the factors behind these deviations, while the final stage of this case study is to provide a response in the form of treatment in a particular context or in commonly called the case study evaluation phase. This study used a qualitative descriptive naturalistic research method to obtain data in a systematic, factual, and accurate. The data in this study are oral and written data. Oral data obtained using data collection techniques such as interviews and observations of the student, while data obtained using a form of writing instruments in the form of tests. The results showed that (1) the difficulty listening to experienced students (X) is caused by a disturbance in the sense of hearing; (2) auditory disorders occur because the student (X) had an accident in public pools; (3) the motivation of the teacher role for the case experienced by the student $(X)$; (4) student $(X)$ requires a special service in the learning process listening skill.

Keywords: listening, case studies, and auditory disorders 


\section{PENDAHULUAN}

Pembelajaran Bahasa Indonesia di Sekolah Dasar hakekatnya bertujuan agar siswa terampil menggunakan $\mathrm{Ba}$ hasa Indonesia untuk berbagai keperluan, terutama untuk berkomunikasi dan berinteraksi dengan orang lain. Pendidikan bagi anak usia dini harus mendapat sorotan yang lebih karena pada usia ini perkembangan kecerdasan anak ditentukan dari pola pendidikan atau pengajaran yang anak tersebut dapatkan. Pola pengajaran yang kurang tepat akan membuat kecerdasan anak tersebut menjadi terhambat dan tidak berkembang secara maksimal. Sebagai tenaga pengajar, sudah sepantasnya kita memberikan pola pengajaran yang maksimal. Pola pengajaran tersebut dapat dikatakan maksimal ketika kita berusaha menyesuaikan pola pengajaran dengan karakteristik siswa tersebut.

Pembelajaran Bahasa Indonesia menjadi perhatian karena pada rentang usia tersebut karena usia tersebut merupakan usia keemasan sesorang dalam pemerolehan dan pembelajaran bahasa. Penguasaan Bahasa Indonesia akan sangat berpengaruh dalam penguasaan ilmu pengetahuan lainnya karena bahasa Indonesia digunakan sebagai bahasa pengantar dalam pembelajaran ilmu pengetahuan di sekolah. Pada saat proses pembelajaran Bahasa Indonesia, seorang guru sebagai pendidik harus mampu memberikan perhatian yang intens terhadap siswa. Perhatian intens tersebut merupakan salah satu cara melihat atau menganalisis penyimpangan yang terjadi pada siswa tersebut.

Bila terjadi suatu hal yang menyimpang dalam pembelajaran ba-hasa Indonesia, penyimpangan tersebut harus segera ditanggapi oleh seorang guru secara profesional sebagai sebuah kasus. Tanggapan, keputusan, dan tindak lanjut sangat penting karena akan berpe- ngaruh dalam jangka pendek maupun jangka panjang terhadap siswa yang bersangkutan, orang tua siswa, dan masyarakat. Perilaku, kebiasaan, kemampuan dan lain-lain dapat dikatakan menyimpang dan dijadikan sebuah kasus jika penyimpangan tersebut terlihat sangat mencolok pada siswa tersebut dibandingkan dengan teman-temannya di kelas.

Penelitian studi kasus dalam bidang pendidikan adalah penelitian yang berupaya menemukan sebuah kasus yang tampak sebagai sebuah penyimpangan, kemudian penyimpangan tersebut dianalisis berdasarkan tahapan untuk melihat faktor-faktor yang melatarbelakangi penyimpangan tersebut, sedangkan tahap akhir penelitian kasus ini adalah memberikan tanggapan berupa perlakuan dalam konteks tertentu atau dalam penelitian studi kasus biasa disebut tahap evaluasi.

Pada penelitian ini, terdapat sebuah kasus dalam pembelajaran Ba-hasa Indonesia. Kasus tersebut berupa kesulitan menyimak dalam pembelajaran $\mathrm{Ba}-$ hasa Indonesia di kelas. Kesulitan menyimak tersebut menjadi hambatan masuknya informasi kepada siswa. Hambatan tersebut dapat berupa salah persepsi atau tidak utuhnya informasi yang sampai kepada siswa. Hal ini jelas akan memberikan dampak negatif terhadap perkembangan kecerdasan dan prestasi siswa tersebut di sekolah. Sejalan dengan hal tersebut Saddhono (2012: 4) mengatakan bahwa "kemapuan menyimak adalah kemampuan bebahasa pertama yang dimilki oleh manusia dalam pemerolehan bahasa". Bertolah dari pendapat tersebut, bisa dikatakan bahwa kemampuan menyimak me-rupakan modal awal seseorang untuk berkomunikasi.

Kesulitan menyimak dalam pembelajaran Bahasa Indonesia akan 
berdampak langsung kepada keterampilan lainnya karena menurut Iskandarwassid \& Suhendar (2011: 227), keterampilan menyimak pada tahapan lebih tinggi mampu menginformasikan lagi pemahamannya melalui keterampilan berbicara maupun menulis.

Unsur terpenting dalam pembelajaran menyimak adalah keterampilan untuk memahami apa yang dikatakan dan diucapkan oleh orang lain atau pembicara. Kesulitan menyimak akan berkaitan langsung dengan masalah pendengaran. Gangguan pendengaran merupakan salah satu penyebab terhambatnya aktivitas menyimak. Hal ini dikarenakan proses menyimak sangat erat kaitannya dengan indera pendengaran, yaitu telinga. Terdapat tahapan dalam proses pembelajaran keterampilan menyimak yaitu 1) mendengar, 2) mengerti, 3) mengevaluasi dan 4) menanggapi. Proses tersebut harus dikuasai siswa dalam pembelajaran menyimak karena apabila ada tahapan yang tidak bisa dilewati dan dikuasai maka pembelajaran keterampilan menyimak akan mengalami kesulitan. Hal tersebut dapat terjadi dikarenakan proses penangkapan bunyi dan proses pemahaman merupakan dua proses yang berlangsung secara bersamaan.

Penelitian ini berangkat dari sebuah pengamatan. Pengamatan guru terhadap seorang siswa yang memiliki kesulitan dalam pembelajaran menyimak. Hal tersebut terlihat menonjol pada saat pembelajaran. Dalam menjawab pertanyaan yang diberikan oleh guru secara lisan, siswa kurang cepat tanggap dan selalu bertanya kepada teman di sebelahnya. Berdasarkan observasi dan pengamatan awal peneliti mendapatkan informasi dari wali kelas siswa tersebut bahwa siswa mendapat gangguan pada indera pendengarannya. Tetapi informasi yang berbeda didapat dari wali kelas sebelumnya, bahwa siswa tersebut tidak mempunyai gangguan pada indera pendengarannya dan tidak pernah mengalami kesulitan dalam pembelajaran keterampilan menyimak di kelas.

\section{KAJIAN TEORETIS}

\section{Studi Kasus}

Menurut Bogdan dan Biklen (dalam Syamsuddin \& Damaianti, 2009: 175) studi kasus merupakan pe-ngujian secara rinci terhadap suatu latar ( $a$ detailed examination of one setting) atau satu orang subjek (one single subject) atau satu tempat penyimpanan dokumen (one singel depository of documents) atau satu peristiwa tertentu (one particular event). Surachmad (1987) membatasi pendekatan studi kasus sebagai suatu pendekatan dengan memusatkan perhatian pada suatu kasus secara intensif dan rinci. Berdasarkan kedua definisi tersebut peneliti dapat menyimpulkan bahwa studi kasus adalah sebuah penelitian yang berangkat dari adanya sebuah kasus baik itu suatu kondisi, orang atau peristiwa. Setelah data pada kasus tersebut didapat lalu dianalisis secara rinci dan intensif.

Dalam melaksanakan penelitian studi kasus, Bogdan dan Biklen (dalam Syamsuddin \& Damaianti, 2009: 184) memberikan petunjuk rancangan dalam bentuk cerebong. Cerobong ini melukiskan proses penelitian yang berawal dari eksplorasi yang bersifat luas dan dalam, kemudian berlanjut dengan aktivitas pengumpulan dan analisis data yang lebih menyempit dan terarah pada suatu topik tertentu.

Terkait dengan penelitian studi kasus, terdapat enam prosedur yang harus dilalui sebagai berikut.

a. Identifikasi Kasus

Tahapan ini merupakan awal dimulainya penelitian studi kasus. Pada tahapan ini peneliti mencoba menge- 
nali atau mendeteksi sebuah kasus. Kasus tersebut dapat ditentukan apabila terjadi di luar kebiasaan yang terjadi.

b. Identifikasi Masalah

Setelah peneliti menemukan sebuah kasus, langkah selanjutnya adalah menentukan masalah yang terdapat pada kasus tersebut.

c. Diagnosis

Pada tahapan diagnosis, peneliti mulai menentukan bentuk masalah berupa kelainan atau ketidakmampuan. Hal tersebut didapat dengan melihat latar belakang penyebabnya atau dengan cara mengidentifikasi gejala yang tampak.

d. Prognosis

Setelah tahapan diagnosis dilakukan peneliti melanjutkan pada tahapan prognosis. Pada tahapan ini peneliti mencoba meramalkan akibat yang akan dialami oleh siswa yang memiliki kasus tersebut.

e. Remedial

Tahapan ini adalah tahapan yang berupaya melakukan penyembuhan atau perbaikan pada siswa yang memiliki kasus. Penyembuhan dan perbaikan tersebut dilakukan dengan melihat karakteristik kasus tersebut.

f. Evaluasi

Tahapan ini adalah tahap terakhir yang dilakukan pada penelitian studi kasus. Peneliti mengadakan sebuah evaluasi akhir dengan mempertimbangkan hasil yang didapat dari lima tahapan sebelumnya.

Tahapan penelitian studi kasus tersebut merupakan tahapan yang runtut. Tiap-tiap tahapan perlu dilakukan secara seksama. Hal tersebut dilakukan agar dapat melihat perkembangan secara sistematis dari siswa yang memiliki kasus kesulitan menyimak.

\section{Keterampilan Menyimak dalam Pembelajaran Bahasa Indonesia}

Keterampilan menyimak merupakan salah satu keterampilan berbahasa yang diajarkan di sekolah dasar sesuai dengan standar isi Kurikulum Tingkat Satuan Pendidikan (KTSP) 2006. Berikut ini akan di uraikan secara singkat pendapat beberapa ahli me-ngenai kegiatan pembelajaran keterampilan menyimak. W.J.S. Poerwadarminta (1982: 847) mengatakan bahwa menyimak adalah mendengarkan (mempertahankan apa yang dikemukakan orang). Menyimak juga dapat diartikan dengan mendengarkan baik-baik. Saddhono (2012: 11) mengatakan bahwa menyimak adalah suatu proses yang menyangkut kegiatan mendengarkan, mengidentifikasi, menginterpretasi, bunyi bahasa, kemudian menilai hasil interpretasi makna dan menanggapi pesan yang tersirat dalam bahan simakkan.

Keterampilan menyimak adalah suatu bentuk keterampilan berbahasa yang bersifat reseptif. Pada waktu proses pembelajaran, keterampilan ini jelas mendominasi aktifitas siswa dibandingkan dengan keterampilan lainnya, termasuk keterampilan berbicara (Iskandarwassid \& Suhendar 2011: 227). Shihabuddin berpendapat menyimak adalah suatu proses kegiatan mendengarkan lambang-lambang lisan dengan penuh perhatian, pemahaman, apresiasi, serta interprestasi untuk memperoleh informasi, merangkap isi serta memahami makna komunikasi yang disampaikan oleh pembicara melalui ujaran atau bahasa lisan (2009: 161). Sejalan dengan hal tersebut, -Saddhono (2012: 4) mengatakan bahwa kemampuan menyimak adalah kemam-puan berbahasa pertama yang dimilki oleh manusia dalam pemerolehan bahasa. Oleh karena itu, kemampuan menyimak 
merupakan modal awal seseorang dalam hal untuk berkomunikasi.

Berdasarkan pemaparan di atas, peneliti dapat menarik kesimpulan bahwa salah satu faktor terpenting keberhasilan pembelajaran Bahasa Indonesia di kelas adalah kemampuan siswa dalam proses menyimak informasi yang diberikan guru pada saat pembelajaran dilakukan.

\section{METODE PENELITIAN}

Penelitian ini menggunakan metode penelitian naturalistik deskriptif kualitatif. Metode penelitian ini digunakan untuk memperoleh data secara sistematis, faktual, dan akurat. Dengan demikian, peneliti berusaha menganalisis data dengan seluruh kekayaan informasi sebagaimana terekam pada data yang telah dikumpulkan. Pada penelitian ini, peneliti mencoba merangkum sebuah fenomena yang terjadi, setelah data dirangkum dan dianalisis peneliti mencoba merancang remedial dan evaluasi yang tepat. Adapun beberapa tahap penelitian di bawah ini.

1) Peneliti menentukan subjek penelitian sebelum melakukan observasi dan wawancara,

2) Penentuan subjek dipilih melalui siswa yang memiliki kasus atau kesulitan pembelajaran yang tampak.

3) Pendekatan dan teknik pengumpulan data yang digunakan adalah metode simak, observasi, rekam, dan tes.

4) Teknik yang digunakan dalam mengolah data adalah dengan cara melihat perkembangan yang muncul dari siswa tersebut dalam beberapa pertemuan.

5) Data dipilah-pilah dan disusun dalam sebuah tabel perkembangan.

Data dalam penelitian ini berupa data lisan dan tulis. Data lisan diperoleh dengan menggunakan teknik pengumpulan data berupa wawancara dan observasi pada siswa. Sedangkan data berupa tulisan diperoleh dengan menggunakan instrumen berupa tes. Data yang muncul akan berupa kesalahan persepsi, penghilangan informasi, dan kesulitan dalam pembelajaran keterampilan menyimak di dalam kelas.

\section{PEMBAHASAN}

\section{Identifikasi Kasus}

Kasus yang dibahas dalam penelitian ini adalah sebuah kesulitan pembelajaran menyimak yang dialami oleh seorang siswi $\mathrm{X}$ (nama disamarkan). Berikut adalah sekilas profil yang menjadi subjek dalam penelitian ini.

$\begin{array}{ll}\text { Nama } & \text { : Siswi X } \\ \text { Usia } & : 10 \text { tahun } \\ \text { Jenis Kelamin } & : \text { Wanita } \\ \text { Kelas } & : \text { 3 SD } \\ \text { Sekolah } & : \text { Sekolah Dasar Inklusi } \\ & \text { X, Kabupaten Ban- } \\ & \quad \text { dung } \\ \text { Alamat Siswa } & \text { : Soreang } \\ \text { Status Sosial } & \text { : Menengah keatas } \\ \text { Tinggal } & \text { : Bersama kedua orang } \\ & \text { tuanya }\end{array}$

\section{Identifikasi Masalah}

Masalah yang dialami oleh subjek penelitian adalah siswi mengalami kesulitan dalam pembelajaran keterampilan menyimak akibat adanya gangguan pada indera pendengarannya. Kesulitan tersebut berpengaruh terhadap pemahaman siswa terhadap materi yang disampaikan oleh guru secara lisan.

\section{Diagnosis}

Diagnosis merupakan istilah (terminology) yang kita adopsi dari bidang medis. Menurut Thorndike dan Hagen (1955: 44), diagnosis dapat diartikan sebagai upaya atau proses mene- 
mukan kelemahan atau penyakit (weakness, disease) apa yang dialami seseorang dengan melalui pengujian dan studi yang seksama mengenai gejalagejalanya (symptons)

Setelah dilakukan pengamatan oleh guru, wawancara dengan orang tua dan bertanya kepada teman-teman dari siswa tersebut. Dapat didiagnosis bahwa siswa tersebut mengalami kesulitan pembelajaran menyimak diakibatkan karena.

a) Siswa mengalami kecelakaan yang mengakibatkan terganggunya indera pendengarannya.

b) Adanya gangguan pendengaran mengakibatkan siswa tersebut mengalami kesulitan dalam pembelajaran menyimak.

c) Gangguan pendengaran tersebut diakibatkan oleh cedera pada organ pendengaran (rumah siput, tulang pendengaran, dan gendang telinga).

d) Siswa tidak dapat secara maksimal mendapatkan informasi atau materi yang disampaikan oleh guru secara lisan.

e) Siswa lebih memilih membaca buku daripada menyimak penjelasan guru.

\section{Prognosis}

Kesulitan pembelajaran keterampilan menyimak akan berdam-pak negatif langsung kepada beberapa faktor, antara lain:

a) Menyimak adalah salah satu bentuk keterampilan yang bersifat reseptif. Keterampilan ini langsung berhubungan dengan dua keterampilan produktif baik itu menulis atau berbicara. Oleh karena itu, apabila siswa mengalami kesulitan dalam pembelajaran menyimak, siswa tersebut akan mengalami hambatan dalam pembelajaran keterampilan menulis dan berbicara. b) Siswa kurang maksimal mendapatkan informasi dan materi yang disampaikan oleh guru secara lisan.

c) Prestasi siswa akan menurun.

d) Siswa menjadi kurang percaya diri dan kurang bisa bersosialisasi dengan teman-temannya.

e) Bila kasus ini tidak segera mendapatkan tindak lanjut akan menggangu perkembangan kecerdasan siswi $(X)$

Kegiatan Observasi dapat dilihat pada bagian berikut ini.

a. Tempat Observasi

Peneliti melakukan kegiatan observasi di salah satu sekolah inklusi di daerah Kabupaten Bandung.

$$
\begin{array}{ll}
\text { Nama Sekolah } & \text { : SD Inklusi X } \\
\text { Provinsi } & \text { : Jawa Barat } \\
\text { Kabupaten } & \text { : Bandung } \\
\text { Kecamatan } & \text { : Baleendah } \\
\text { Alamat } & \text { : Baleendah }
\end{array}
$$

Sekolah Inklusi $\mathrm{X}$ ini adalah sekolah regular atau sekolah biasa tetapi memiliki konsep menerima ABK (Anak Berkebutuhan Khusus) dan menyediakan sistem layanan pendidikan yang disesuaikan dengan kebutuhan anak tanpa kebutuhan khusus dan ABK mela-lui adaptasi kurikulum, pembelajaran, penilaian, dan sarana prasarananya.

b. Waktu Observasi

Kegiatan observasi dilakukan selama bulan Desember 2013. Jadwal penelitian dilakukan setiap hari selasa dan kamis dimulai pada pukul 08.00 hingga pukul 13.00 WIB.

c. Subjek Penelitian

Setelah melakukan pengamatan sebelumnya dan mendapat saran dari guru-guru di sekolah tersebut, peneliti berhasil menemukan subjek penelitian yang tepat yaitu siswa yang mengalami kesulitan menyimak dalam pembelajaran Bahasa Indonesia. 
Berikut adalah profil subjek dalam penelitian ini.

$\begin{array}{ll}\text { Nama } & : \text { Siswi }(\mathrm{X}) \\ \text { Usia } & : 10 \text { tahun } \\ \text { Jenis Kelamin } & : \text { Wanita } \\ \text { Kelas } & : \text { S SD } \\ \text { Sekolah } & : \text { Sekolah Dasar Inklusi } \\ \text { X, Kabupaten } & \text { Bandung } \\ \text { Alamat Siswa } & : \text { Soreang } \\ \text { Status Sosial } & : \text { Menengah keatas } \\ \text { Tinggal } & : \text { Bersama kedua orang } \\ \text { tuanya } & \end{array}$

Berkenaan dengan subjek dan sumber data pada penelitian yang akan dilakukan, berikut ini pemaparan yang berupa keterangan singkat yang akan menjadi informasi penting berkaitan dengan penelitian ini. Siswi (X) adalah siswa kelas 3 sekolah dasar, siswi (X) adalah siswi normal dan tidak memiliki cacat fisik bawaan. Siswi (X) merupakan siswi yang memiliki tingkatan ekonomi menengah ke atas dan tidak mengalami kegagalan pola asuh oleh kedua orang tuanya.

Siswi (X) dicurigai mengalami gangguan menyimak. Hal ini ditujukan saat pembelajaran keterampilan menyimak dilaksanakan, siswi selalu tertinggal dalam pembelajaran ini, merespon pembelajaran tersebut sebelumnya dengan lambat atau bahkan sering bertanya kepada teman yang ada di sebelahnya.

Kasus yang terjadi pada Siswi (X) ini termasuk kasus yang unik, karena kesulitan dalam pembelajaran menyimak ini dimulai pada saat siswi (X) duduk di kelas 2 semester kedua hingga sekarang. Berdasarkan penjelasan guru dan wali kelasnya sebelum-nya siswi (X) tidak mengalami kesulitan dalam pembelajaran menyimak di dalam kelas. Oleh karena itu dalam penelitian ini peneliti akan mencoba mencari faktor yang menjadi penyebab perubahan ter- sebut terjadi dan mencari jalan keluarnya agar tidak ada.

d. Wawancara

Wawancara merupakan teknik pengumpulan data dengan cara tanya jawab dengan beberapa pihak yang terkait dengan penelitian ini antara lain siswa yang memiliki kasus, teman-temannya, orang tua, wali kelas dan guruguru di sekolah tersebut. Pertanyaan yang dirancang disesuaikan dengan data yang diperlukan dalam penelitian ini.

\section{a) Wawancara dengan wali kelas sekaligus guru Bahasa Indonesia Siswi (X)}

Berikut ini adalah hasil wawancara dengan wali kelas siswa yang memiliki kasus. Wali kelas siswa tersebut sekaligus sebagai guru mata pelajaran Bahasa Indonesia.

Data pertama berupa profil kedua orang tua siswa.

Nama ayah : Bapak X (nama disamarkan)

Pekerjaan : Pegawai Swasta

Agama : Islam

Pendidikan : :S1

Alamat : Jalan Raya Soreang

Nama Ibu : Ibu X (nama

disamarkan)

Pekerjaan : Wiraswasta

Agama : Islam

Pendidikan : D3

Alamat : Jalan Raya Soreang

Data kedua berupa keterangan mengenai sebab dan akibat Siswi (X) mengalami kesulitan dalam pembelajaran keterampilan menyimak. Agar mudah dipahami oleh pembaca pemaparan jawaban guru telah ditranskrip dan disesuaikan oleh peneliti. 
1) Bagaimana kondisi Siswi (X) di kelas dalam pembelajaran seharihari?

Siswi $(\mathrm{X})$ adalah seorang siswa yang memiliki tingkat kecerdasan yang cukup baik. Siswi (X) selalu mengerjakan tugas yang diberikan oleh guru tetapi dalam pembelajaran di kelas saat guru menerangkan siswi (X) kurang bisa berkonsentrasi dan lebih banyak melamun dan asik sendiri. Hal ini diakibatkan oleh adanya gangguan pendengaran. Dalam pergaulan dengan teman-temannya, Siswi (X) tidak mengalami kesulitan. Siswi (X) memiliki banyak teman di kelas, perilaku teman-temannya pun biasa saja kepada siswi (X), tidak pernah membeda-bedakan atau mengejek Siswi (X) .

Pada saat pembelajaran menyimak, siswi (X) kurang bisa mengikuti dengan baik. Siswi (X) kebanyakan melamun, asik sendiri atau memilih untuk membaca buku. Pada saat ditanya oleh guru mengenai materi yang dijelaskan, siswi (X) sering bertanya kembali kepada teman yang ada di sebelahnya atau di depannya mengenai bentuk pertanyaan yang ditanyakan oleh guru. Terkadang siswi (X) bisa menjawabnya atau sering juga tidak bisa menjawab. Kurang maksimalnya pem-belajaran menyimak berpengaruh lang-sung pada saat siswi (X) mengikuti ulangan dan ujian. Siswi (X) tidak bisa menjawab dengan tepat beberapa soal yang materinya dijelaskan secara lisan oleh guru.

\section{2) Bagaimana latar belakang orang tua} siswi $(\mathrm{X})$ ?

Tingkat ekonomi kedua orang tua siswi (X) berada pada tingkatan menengah ke atas. Ayah siswi (X) seorang kepala pegawai di perusahaan swasta sedangkan ibunya adalah seorang wiraswasta di bidang garmen. Lingkungan tempat tinggal siswi (X) berada di se- buah komplek perumahan di daerah Soreang Kabupaten Bandung.

Menurut keterangan guru, siswi (X) tidak mengalami kegagalan pola asuh atau kurangnya perhatian orang tua, hal itu dikarenakan orang tua siswi (X) selalu menyempatkan untuk mengantar atau menjemput siswi (X) di sekolah. Pada saat pembagian raport atau acara sekolah, kedua orang tua siswi (X) selalu mendampingi Siswi (X) ke sekolah. Pengamatan guru di sekolah melihat bentuk perhatian kedua orang tua siswi (X) biasa-biasa saja, tidak ada yang menyimpang.

3) Apakah latar belakang orang tua siswi (X) berpengaruh pada kesulitan pembelajaran menyimak ?

Seperti yang telah saya jelaskan pada jawaban sebelumnya, latar belakang dan lingkungan tempat tinggal Siswi (X) tidak berpengaruh pada kesulitan pembelajaran menyimak di kelas. Menurut keterangan Siswi (X), Bapak dan ibunya selalu bergantian menemani siswi (X) belajar di rumah-nya, menjemput di sekolah dan di tempat lesnya. Dengan melihat latar belakang pendidikan orang tuanya yang cukup baik siswi (X) pasti mendapat bimbingan pembelajaran di rumahnya dengan baik.

4) Apakah perilaku teman-teman siswi (X) berpengaruh kepada proses pembelajaran menyimak ?

Perilaku teman-teman siswi (X) di kelas biasa saja, tidak ada perilaku yang menyimpang yang dilakukan oleh teman-temannya kepada siswi $(\mathrm{X}) \mathrm{mi}$ salnya menjauhi atau mengejeknya. Siswi (X) memiliki banyak teman dan siswi $(X)$ adalah seorang anak yang mudah bergaul. 
5) Apa penyebab siswi (X) mengalami kesulitan dalam pembelajaran menyimak?

Berdasarkan pengamatan yang telah dilakukan, siswi (X) mengalami kesulitan pembelajaran menyimak diakibatkan oleh adanya gangguan pada indera pendengarnnya. Gangguan ini terjadi pada saat siswi (X) berada di kelas 3 karena menurut keterangan wali kelas siswi (X) pada saat berada di kelas 2 Siswi (X) tidak mengalami gangguan pendengaran.

Menurut kabar yang beredar dan konfirmasi langsung dengan kedua orang tuanya. Pada saat liburan kenaikan sekolah Siswi (X) bersama saudarasaudaranya berlibur ke salah satu waterbom yang berada di Jakarta. Siswi (X) mengalami kecelakaan pada saat berenang di kolam renang umum. Siswi (X) bertabrakan dengan pengunjung lain, telinga Siswi $(\mathrm{X})$ beradu dengan kepala, saat itu juga telinga siswi (X) mengeluarkan darah. Kedua orang tua Siswi (X) langsung membawa siswi (X) ke rumah sakit untuk diperiksa.

Setelah mendapat penanganan dan diperiksa oleh dokter spesialis THT siswi (X) mengalami kerusakan pada telinga sebelah kanan. Kerusakan terjadi pada bagian (rumah siput, tulang pendengaran, dan gendang telinga). Kerusakan tersebut berdampak kurang maksimalnya pendengaran Siswi (X). Pengobatan rutin dan therapy terus dilakukan oleh kedua orang tua Siswi (X). Perkembangan pemulihan indera pendengaran Siswi (X) berjalan dengan intens.

Siswi (X) mengalami trauma bermain di air. Pada saat kegiatan renang yang rutin diadakan oleh pihak sekolah dan guru olah raga, siswi (X) hanya bermain di pinggir kolam sekedar memasukan setengah badannya dan tidak menyelam. Pada saat tes berenang pun, siswi (X) tidak mau melakukannya.

6) Apakah Ibu dan guru-guru bidang studi memberikan bentuk layanan khusus kepada Siswi (X) dalam pembelajaran menyimak? Jika ada, bagaimana bentuk layanan khusus yang diberikan?

Layanan khusus dalam pembelajaran keterampilan menyimak Bahasa Indonesia diberikan dalam bentuk guru mendatangi langsung siswi (X) ke tempat duduknya. Guru menjelaskan lagi secara lantang materi yang telah guru sampaikan sebelumnya. Tetapi layanan ini mengalami kesulitan pada saat siswi (X) mengerjakan tugas sering terlambat karena waktu teman-temannya mengerjakan tugas siswi $(\mathrm{X})$ sedang mendapat layanan khusus. Hal ini berdampak pada terlantarnya siswa dan terlambatnya jadwal penyampaian materi untuk keseluruhan siswa.

Pelayan khusus lainnya adalah dengan cara guru menyiapkan dalam bentuk catatan mengenai materi yang akan disampaikan lalu memberikan kepada Siswi (X) untuk dibaca saat pembelajaran. Kurang maksimalnya pembelajaran menyimak yang diakibatkan adanya ganggguan indera pendengaran Siswi $(X)$ terwakilkan dengan materi yang dibaca oleh siswi (X) saat pembelajaran.

Selain itu guru selalu menempatkan siswi (X) duduk di posisi bagian depan. Hal itu dilakukan untuk memaksimalkan proses menyimak Siswi (X) pada saat guru menjelaskan materi. Hal ini dirasa alternatif yang paling baik, karena dengan Siswi (X) duduk di depan suara guru pada saat menjelaskan dapat didengar dengan baik. 


\section{b) Wawancara dengan orang tua Siswi (X) .}

Wawancara dengan orang tua Siswi (X) dilakukan dengan situasi santai. Peneliti tidak menyiapkan daftar pertanyaan sebelumnya. Wawancara meliputi pemaparan mengenai penyebab Siswi (X) mengalami gangguan indera pendengarannya.

Berikut adalah pemaparan orang tua siswi (X) yang telah peneliti simpulkan.

Siswi (X) adalah anak kedua dari tiga bersaudara. Siswi (X) adalah anak perempuan satu-satunya di keluarga. Siswi (X) terlahir normal dan sehat. Perkembangan fisik dan kecerdasan Siswi (X) sesuai dengan anak normal lainnya.

Sebelum terjadinya kecelakaan yang mengakibatkan terganggunya pendengaran, Siswi (X) adalah anak yang berprestasi. Hal itu dibuktikan dengan prestasi yang didapatkannya di sekolah. Siswi (X) selalu mendapat peringkat 3 besar di kelas. Di rumah Siswi (X) adalah anak yang periang dan hobi bernyanyi tetapi sekarang hal tersebut sudah jarang dilakukan Siswi (X) .

Pihak keluarga melakukan hal yang terbaik untuk penyembuhan telinga Siswi (X). Terapi yang rutin dan memberikan suplemen herbal khusus adalah salah satu cara untuk menyembuhkan pendengaran Siswi (X). Sama seperti yang dijelaskan oleh wali kelas Siswi (X). Penyebab terganggunya pendengaran Siswi (X) diakibatkan oleh kecelakaan yang terjadi pada saat Siswi (X) berenang. Akibat kecelakaaan tersebut Kerusakan terjadi pada bagian telinga Siswi (X) meliputi rumah siput, tulang pendengaran, dan gendang telinga. Orang tua Siswi (X) sangat menyesalkan kejadian ini bisa terjadi, tetapi orang tua Siswi (X) menerima musibah ini dengan lapang dada dan terus berusaha dengan berbagai cara untuk penyembuhan Siswi $(\mathrm{X})$.

\section{Remedial}

Remedial adalah tahapan yang berupaya melakukan penyembuhan atau perbaikan pada siswa yang memiliki kasus. Penyembuhan dan perbaikan tersebut dilakukan dengan melihat karakteristik kasus tersebut.

Remedial dalam penelitian ini bebentuk layanan khusus dalam proses pembelajaran yang menyesuaikan dengan karakteristik siswi (X). Seperti yang telah dipaparkan sebelumnya pada saat wawancara, guru telah memberikan bentuk layanan khusus kepada Siswi (X), tetapi dengan melihat gambaran yang tampak pada kasus ini, peneliti memberikan masukan remedial yang terdiri dari beberapa bentuk, antara lain.

a) Pendekatan kepada siswa dan orang tua

b) Tugas Individu

c) Pendekatan pada saat pembelajaran

d) Tutor Sebaya

e) Model pembelajaran dengan teknik rekam

Pendekatan kepada siswa dan orang tua dilakukan dengan cara memberikan semangat dan motivasi agar siswa tidak merasa malu dan tertekan dengan gangguan pendengaran yang dialaminya, menerima keluhan dan merespon dengan cepat keluhan tersebut dalam bentuk nyata. Orang tua juga diberikan pengertian agar terus bersabar dan berusaha untuk proses penyembuhan siswi (X).

Tugas Individu adalah bentuk tes yang disesuaikan dengan kesulitan siswi (X). Bentuk tugas individu tersebut dirancang melalui beberapa tahapan sebagai berikut:

a) Pembelajaran dengan layanan khusus

b) Tes dilakukan dalam proses ulangan 
c) Analisis hasil tes untuk mengetahui bagian-bagian yang tidak dimengerti oleh

d) Siswi (X)

e) Tugas individu dirancang dengan melihat kepada hasil analisis tes sebelumnya.

f) Tugas individu diberikan kepada Siswi (X) dalam bentuk pekerjaan rumah.

g) Hasil tugas Individu dianalisis untuk proses evaluasi.

Tutor sebaya adalah pendekatan yang paling tepat untuk siswi (X), karena dengan pendekatan ini Siswi (X) pasti akan merasa tidak tertekan dan lebih nyaman. Tutor sebaya adalah menunjuk satu atau dua teman dekat Siswi (X) untuk menjadi pembimbing Siswi (X) saat pembelajaran. Jika Siswi (X) mengalami kesulitan dalam pembelajaran menyimak teman-temannya dapat membantu. Agar tidak terjadi ketergantungan bantuan dari temannya, guru harus bisa memberikan pemahaman kepada tutor agar memberikan bantuan sesuai dengan porsi yang ditentukan.

Proses selanjutnya adalah perancangan model pembelajaran menyimak. Model pembelajaran yang dirancang adalah model pembelajaran menyimak dengan teknik rekam. Model pembelajaran dengan teknik rekam adalah model pembelajaran yang memanfaatkan alat perekam untuk merekam penjelasan guru. Hal ini dilakukan untuk membantu siswi (X) dalam pembelajaran keterampilan menyimak. Pada saat siswi (X) menyimak dan kurang bisa menerima, siswi $(X)$ dapat mendengarkannya kembali rekaman dari alat perekam tersebut.

\section{Evaluasi}

Tahapan ini adalah tahap terakhir yang dilakukan pada penelitian studi kasus. Peneliti mengadakan sebuah evaluasi akhir dengan mempertimbang-kan hasil yang didapat dari lima tahapan sebelumnya. Artinya pada tahapan ini dilakukan perbaikan berdasarkan data yang ada.

Tahapan penelitian studi kasus tersebut merupakan tahapan yang runtut. Tiap-tiap tahapan perlu dilakukan secara seksama. Hal tersebut dilakukan agar dapat melihat perkembangan secara sistematis penelitian pada siswa yang memiliki kasus kesulitan menyimak.

Pemaparan evaluasi dalam penelitian ini adalah sebagai berikut:

a) Kesulitan pembelajaran menyimak yang dialami siswi (X) disebabkan oleh terganggunya indera pendengaran.

b) Gangguan indera pendengar terjadi karena siswi (X) mengalami kecelakaan di kolam renang umum. Kerusakan indera pendengar terjadi pada bagian rumah siput, tulang pendengaran, dan gendang telinga.

c) Motivasi dari guru sangat berperan untuk kasus yang dialami oleh Siswi (X). Motivasi diperlukan untuk meningkatkan semangat siswi dalam proses pembelajaran keterampilan menyimak.

d) Siswi (X) memerlukan layanan khusus dalam proses pembelajaran keterampilan menyimak. Layanan yang paling tepat diberikan adalah tutor sebaya dan model pembelajaran dengan teknik rekam. Dengan bentuk layanan khusus seperti ini mempermudah siswa memahami informasi, siswa merasa nyaman dan tidak tertekan dan dapat meningkatkan percaya diri siswa dalam pembelajaran. 


\section{SIMPULAN}

Kesulitan menyimak tersebut menjadi hambatan masuknya informasi kepada siswa. Hambatan tersebut dapat berupa salah persepsi atau tidak utuhnya informasi yang sampai kepada siswa. Hal ini jelas akan memberikan dampak negatif terhadap perkembangan kecerdasan dan prestasi siswa tersebut di sekolah. Adapun tahapan-tahapan dalam penelitian studi kasus ini adalah (1) identifikasi kasus; (2) identifikasi masalah; (3) diagnosis, (4) prognosis; (6) remedial, dan (7) melakukan evaluasi.

Hasil penelitian menunjukkan bahwa (1) kesulitan menyimak yang dialami Siswi (X) disebabkan oleh terganggunya indera pendengaran; (2) dangguan indera pendengar terjadi karena siswi (X) mengalami kecelakaan di kolam renang umum. Kerusakan indera pendengar terjadi pada bagian rumah siput, tulang pendengaran, dan gendang telinga, (3) motivasi dari guru sangat berperan untuk kasus yang dialami oleh Siswi (X). Motivasi diperlukan untuk meningkatkan semangat siswa dalam proses pembelajaran keterampilan menyimak, (4) Siswi (X) memerlukan layanan khusus dalam proses pembelajaran keterampilan menyimak. Layanan yang paling tepat diberikan adalah tutor sebaya dan model pembelajaran dengan teknik rekam. Dengan bentuk layanan khusus seperti ini mempermudah siswa memahami informasi, siswa merasa nyaman dan tidak tertekan dan dapat meningkatkan percaya diri siswa dalam pembelajaran.

\section{DAFTAR PUSTAKA}

Iskandarwassid \& Sunendar.D. 2011. Strategi pembelajaran bahasa. Bandung: Rosda
Poerwadarminta, W.J.S.1982. Kamus umum bahasa indonesia. Jakarta: Balai Pustaka

Saddhono. 2012. Meningkatkan keterampilan berbahasa indonesia. Bandung: Karya Putra Darwanti.

Shihabuddin. 2009. Modul evaluasi pengajaran bahasa indonesia. Bandung: SPS UPI

Sugiyono. 2012. Metode penelitian kuantitatif, kualitatif dan $r \& d$. Bandung: Alfabeta

Suracmad, W. 1982. Pengantar penelitian. Bandung: Tarsito

Syamsuddin \& Damaianti. 2009. Metode penelitian pendidikan bahasa. Bandung: Rosda 